NBER WORKING PAPER SERIES

\title{
INCARCERATION LENGTH, EMPLOYMENT, AND EARNINGS
}

\author{
Jeffrey R. Kling \\ Working Paper 12003 \\ http://www.nber.org/papers/w12003
NATIONAL BUREAU OF ECONOMIC RESEARCH
1050 Massachusetts Avenue
Cambridge, MA 02138
January 2006

Assistance in data production was generously provided by Steve Schlesinger and Cathy Whitaker at the Administrative Office of the U.S. Courts, David Jones at the California Employment Development Department, John Scalia at the Bureau of Justice Statistics, WIlliam Sabol at the Urban Institute, William Bales, John L. Lewis, Brian Hays, and Stephanie Bontrager at the Florida Department of Corrections, Sue Burton at the Florida Department of Law Enforcement, and Duane Whitfield at the Florida Education and Training Placement Information Program. Thu Vu provided valuable research assistance. Ibenefitted greatly from the advice of Joshua Angrist, Jerry Hausman, and Lawrence Katz. Helpful comments were also made by Daron Acemoglu, James Anderson, Marianne Bertrand, Shawn Bushway, David Card, Ken Fortson, Jane Garrison, Kara Kling, Alan Kreuger, David Lee, Jeffrey Liebman, Mike Piore, Anne Piehl, Steve Pishke, Whitney Newey, John Tyler, Bruce Western, William Wheaton, numerous seminar and the referees. This research was partially supported with grants from the National Science Foundation (9530182 and 9876337), the Alfred P. Sloan Foundation, and the Russel Sage Foundation. Additional support was provided by the Princeton Office of Population Research (NICHD 5P30-HD32030), and the Princeton Industrial Relations Section. The views expressed herein are those of the author(s) and do not necessarily reflect the views of the National Bureau of Economic Research.

(C2006 by Jeffrey R. Kling. All rights reserved. Short sections of text, not to exceed two paragraphs, may be quoted without explicit permission provided that full credit, including $\odot$ notice, is given to the source. 
Incarceration Length, Employment, and Earnings

Jeffrey R. Kling

NBER Working Paper No. 12003

January 2006

JEL No. J24, K42

\begin{abstract}
This paper estimates effects of increases in incarceration length on employment and earnings prospects of individuals after their release from prison. I utilize a variety of research designs including controlling for observable factors and using instrumental variables for incarceration length based on randomly assigned judges with defferent sentencing propensities. The results show no consistent evidence of adverse labor market consequences of longer incarceration length using any of the analytical methods in either the state system in Florida or the federal system in California.

Jeffrey R. Kling

The Brookings Institution

1775 Massachusetts Ave NW

Washington, DC 20036

and NBER

jkling@brookings.edu
\end{abstract}


The fraction of the American population that has served time in state and federal prisons is large, and has been growing over time. In 2001, 17 percent of African-American males had ever been incarcerated, up from nine percent in 1974; if current incarceration rates remain unchanged, 32 percent of African-American males born in 2001 will go to prison at some point during their lifetimes (Thomas P. Bonczar, 2003).

Concurrent with the increased fraction of individuals ever imprisoned has been the increased duration of incarceration. For example, the federal Sentencing Reform Act, which was implemented in 1987, increased the lengths of the maximum sentences that individuals could expect to serve for various offenses, eliminated probation, and decreased the potential for good behavior to reduce the amount of time served -- effectively doubling average time served in prison (William J. Sabol and John McGready, 1999). Although states vary widely in their incarceration policies, many have adopted truth-in-sentencing laws that involve requirements similar to federal guidelines that prisoners serve at least 85 percent of the sentence (Paula M. Ditton and Doris J. Wilson, 1999). From 1987 to 1996, time served in state prisons increased by 40 percent or more, depending upon the offense (Alfred Blumstein and Allen J. Beck, 1999).

The number of prisoners released each year has increased threefold in the past two decades, to over half a million per year (James P. Lynch and Sabol, 2001). A key element of successful reintegration into society after release is believed to be employment in the legitimate mainstream economy. Most previous research about the effects of incarceration on labor market outcomes has found large effects of incarceration, but has focused on the effect of serving some time in jail or prison, versus serving no time. ${ }^{1}$ Other research has focused on the effects of arrests

\footnotetext{
${ }^{1}$ For a review, see Bruce Western, Jeffrey R. Kling, and David F. Weiman (2001). Joel Waldfogel (1994) and Richard B. Freeman (1992) find large effects of having been incarcerated on income and employment, respectively, with decreases on the order of 25 percent for those who served jail or prison terms. Western (2002) finds large effects of having been incarcerated on both wages (10 to 20 percent) and wage growth (30 percent) of young men.
} 
and convictions on labor market outcomes. ${ }^{2}$ Relatively little is known about the effects of incarceration length on labor market outcomes, although some related work suggests substantial negative effects on earnings. ${ }^{3}$ Yet, sentencing commissions need information on subsequent labor market impacts to make informed decisions about the total costs of changes in incarceration length, since effects on employment and earnings would directly affect individuals, their families (through family income and child support), and government tax revenue long after the incarceration spells themselves have ended.

Both the previous related literature and the more prominent theoretical arguments suggest a null hypothesis of a large negative effect of incarceration length on subsequent labor market outcomes. Most prominent among the proposed theoretical mechanisms are those involving worker productivity; there could be negative effects of lost work experience and a more general deterioration in human capital as skills may go unused during incarceration. Another possibility is that criminal background and its associated stigma may be more salient to employers after longer incarceration spells, although this mechanism may work primarily through conviction

\footnotetext{
${ }^{2}$ For reviews of the literature on crime and labor markets, see Freeman (1999) and Shawn Bushway and Peter Reuter (2002). Waldfogel (1994) finds small negative effects on income for conviction in federal crimes that do not involve a breach of trust, and moderately larger negative effects when a breach of trust is involved. Most previous research has studied young men. Jeffrey Grogger (1995) presents results on the temporary negative impact of arrests. Grogger (1995) and Freeman (1992) both find small negative effects for conviction. Daniel Nagin and Waldfogel (1995) actually find positive effects of conviction on youth's later earnings, which they interpret as an indication that convicted youths are taking jobs in spot labor markets that have higher initial wages but lower longterm earnings trajectories.

${ }^{3}$ Karen E. Needels (1996) examines how the percentage of time offenders were incarcerated over an eight-year period (1976-1983) affected labor market outcomes during the subsequent nine-year period. The sample members were all inmates originally released in 1976 as part of the Transitional Aid Research Project in Georgia, and the time served measures the extent of recidivism rather than differences in initial lengths of incarceration spells. The labor market outcome data, available from 1983-1991, was from the Unemployment Insurance system in Georgia. Needels finds no significant effect for employment, and finds that an additional year of incarceration reduced total earnings from 1983-1991 by about 12 percent. Much of this reduction is associated with the percentage of time incarcerated from 1983-1991. John R. Lott (1992a) finds no significant relationship between prison sentence length and the difference in income before and after conviction for federal drug offenders. Lott (1992b) finds very large effects of prison sentence length on earnings for federal fraud and embezzlement offenders, where a one-month increase in sentence length is associated with a decline in income of 5.5 to 32 percent, depending upon the specification. These specifications constrain the effect of serving any prison time (i.e., the first month) and the effect of additional months to be the same.
} 
rather than incarceration length. Alternatively, longer incarceration length may allow the criminal justice system to reduce recidivism and encourage work through rehabilitative programs or post-release supervision. And direct social contacts with non-incarcerated criminal peers in the community may erode during prison, making legitimate work relatively more attractive after release from a longer incarceration spell.

In brief, I find in this analysis that there is no substantial evidence of a negative effect of incarceration length on employment or earnings. In the medium term, seven to nine years after incarceration spells began, the effect of incarceration length on labor market outcomes is negligible. In the short term, one to two years after release, longer incarceration spells are associated with higher employment and earnings -- findings largely explained by differences in offender characteristics and by incarceration conditions, such as participation in work release programs. While no single analytical method or data source provides irrefutable evidence, the use of multiple methods and data sources in this paper helps corroborate these findings.

\section{Analytical Methods}

Any credible assessment of the effects of incarceration length must address the analytical problem that prison sentences are related to offense severity and criminal history. A simple comparison of groups serving one year versus four years in prison does not represent the counterfactual of interest -- what would have happened to the group serving one year if they had instead served four years. In this paper I use various research designs to approximate this counterfactual; in particular, I control for observable factors, account for pre-existing differences in labor market prospects, and rely on variation within sentences that is not related to individual characteristics, using randomly assigned judges to form instrumental variables for sentence length. Collaboration with numerous government agencies produced data for this study from the 
state prison system in Florida and the federal judicial system in California that links information about offender characteristics, incarceration experiences, and approximately ten years of earnings data reported through the Unemployment Insurance (UI) system.

As a baseline for comparison, I first examine the simple association between incarceration length and labor market outcomes such as employment and earnings. Let $Y$ denote the outcome and $S$ denote the incarceration spell length, and let the subscript $i$ refer to an individual. An ordinary least squares (OLS) regression of this relationship is in equation (1). (1) $\quad Y_{i}=S_{i} \gamma_{1}+\varepsilon_{i 1}$

The outcomes I use, such as the individual's average quarterly earnings, are defined for all individuals at a specified amount of time relative to the incarceration spell.

The first research design, presented in equation (2), includes covariates to adjust for observable differences in individual characteristics $(X)$ that may be correlated with both incarceration length and labor market outcomes after the incarceration spell.

(2) $\quad Y_{i}=S_{i} \gamma_{2}+X_{i} \beta_{2}+\varepsilon_{i 2}$

The second research design controls for estimated pre-existing differences. Even among individuals with similar individual characteristics, it may be the case that outcomes prior to the incarceration spell were associated with incarceration length. For the California data used in this paper, the sample size with observations on both pre- and post-spell outcomes for the same individuals is too small for useful analysis. In order to estimate the extent of any pre-existing differences, I impose a modeling assumption that the association between incarceration length and pre-spell outcomes is stable over time. For equation (3), the data include individuals on whom I have either only post-spell outcomes or only pre-spell outcomes, with one observation per individual. $S$ is the length of the incarceration spell (or the upcoming incarceration spell, for 
individuals with pre-spell outcomes). $D$ is an indicator for former inmates with observed postspell outcomes, where $D_{i} S_{i}$ is the interaction of $D$ and $S . D$ is also included in $X$.

$$
Y_{i}=S_{i} \gamma_{30}+D_{i} S_{i} \gamma_{31}+X_{i} \beta_{30}+\varepsilon_{i 3}
$$

The coefficient of interest is $\gamma_{31}$, the effect of incarceration length on the outcome after controlling for estimated pre-existing differences -- that is, the difference between the associations post-spell and pre-spell (with the pre-spell estimate being $\gamma_{30}$ ).

The third research design controls for actual pre-existing differences, using data from the Florida system which has more extensive information on outcomes both before and after incarceration spells for the same individuals. $\Delta Y$ denotes the change in the outcome for an individual before and after the incarceration spell, as shown in equation (4).

$$
\Delta Y_{i}=S_{i} \gamma_{4}+X_{i} \beta_{4}+\varepsilon_{i 4}
$$

When $X$ is not included in equation (4), estimation is identical to an individual fixed effect model. Inclusion of $X$ controls for individual characteristics associated with changes in the outcome that may also be correlated with incarceration length.

The fourth research design is an alternative strategy for estimating the effect of incarceration length on employment and earnings, using the judge assigned to cases to create an instrumental variable for incarceration length. Intuitively, this research design compares groups of otherwise similar individuals who have shorter or longer prison sentences because their cases were randomly assigned to judges that showed different levels of leniency in sentencing. Equation (5) is used to estimate the effect on prison sentence length of the judge $(Z)$ assigned to the case, where cases are subscripted by $j .{ }^{4} \mathrm{~A}$ set of indicator variables for calendar quarter in

\footnotetext{
${ }^{4}$ In the California data, 48 percent of cases have multiple defendants. In order to reduce the sampling variability that would result from randomly selecting one defendant per case, equation (5) is estimated at the case level, averaging the prison sentences of multiple defendants with the same docket number. For the 0.6 percent of all cases in which all defendants were not assigned in the same calendar quarter to the same judge, one defendant was randomly
} 
each district office $(Q)$ is included to account for the fact that assignment of cases to judges is randomly determined conditional on the date and location of case filing.

(5) $\quad S_{j}=Z_{j} \pi+Q_{j} \theta+\eta_{j}$

I use the parameter estimate $\hat{\pi}$ from equation (5) to construct the instrumental variable $Z \hat{\pi}$ based on the randomly assigned judge. This instrument is assumed to affect labor market outcomes through incarceration length. I then use two-stage least squares estimation of equation (2) to estimate the effect of incarceration length, with $S$ as the endogenous variable and $Z \hat{\pi}$ as the excluded instrument. This research design requires information on all cases assigned to judges, including those not resulting in any prison time, which is available in the California data.

\section{Data}

The data used in this paper come from the administrative records of the state prison system in Florida and the federal judicial system in California, each linked to state administrative records about quarterly earnings. Nationally, in June 2003 there were 1.2 million inmates in state prisons, 690,000 inmates in local jails, and 160,000 inmates in federal prisons (Paige M. Harrison and Jennifer C. Karberg, 2003). Roughly speaking, prisons are used in the U.S. for longer sentences (often at least a year), while local jails are used for shorter sentences. Although most inmates are in state systems, the federal system handles cases that directly involve the federal government or statutorily fall within federal jurisdiction.

The Florida data were produced for this study in collaboration with the Florida Department of Corrections, matched to quarterly earnings data for 1993:3 through 2002:1 from the UI system by social security number (SSN). The California data were produced under special confidential data-sharing agreements with the Administrative Office of the U.S. Courts (for data

selected and all defendants with the same judge and filing quarter were aggregated to represent the case. 
on terminated federal cases with individual and judge identifiers), California pre-trial services agencies (for demographic data and SSNs), and the California Employment Development Department (for quarterly UI data from 1987:2 to 1997:1). Actual time served is not observed in the California data, so the expected spell length is based on the sentence length and historical averages of proportion of time served published by the U.S. Department of Justice (1996). Additional details are available in the Data Appendix.

In terms of demographic characteristics, these samples are largely male. The majority of the Florida sample is African-American, while the California samples have relatively more whites, Hispanics, and other races. The Florida sample is younger, less-educated, has a more extensive criminal history, and has more violent offenders; in these respects, the Florida sample is similar to inmate populations in other state systems -- all of which tend to differ substantially from the federal system (Caroline W. Harlow, 1994). Florida is also fairly representative of other states in terms of the race and ethnicity of offenders. ${ }^{5}$

The analysis focuses on three outcomes: fraction of quarters with any positive earnings, fraction of quarters with earnings above the 2002 poverty threshold (\$9359 per year, or \$2340 per quarter), and average quarterly earnings including zeros. ${ }^{6}$ The pre- and post-spell employment and earnings rates from the administrative data are very low in both states, and similar to those of inmate populations in several other states. ${ }^{7}$

\footnotetext{
${ }^{5}$ Note that the distribution of Hispanic inmates is highly skewed among states, with two-thirds of incarcerated Hispanics in California, Texas, and New York (which only have one-third of the overall prison population among them); Florida and other states have a much lower proportion of Hispanic inmates (Harrison, 2002).

${ }^{6}$ For simplicity, the quarterly earnings data in this paper consist of a single summary measure of labor market outcomes for each individual, averaged over three calendar quarters to reduce transitory variability. Quarterly earnings are adjusted to 2002 real dollars based on the seasonally-adjusted national Consumer Price Index (CPI), and are top-coded at ten times the 2002 poverty rate ( $\$ 23,398$ per quarter).

${ }^{7}$ See Needels (1996) for Georgia, Sabol (2006) for Ohio, and Becky Pettit and Christopher Lyons (2006) for Washington state. The average fraction with positive earnings in the administrative earnings data for Florida one year prior to the incarceration spell was only about one-third. However, nearly two-thirds of the Florida sample selfreported that they were employed at the time of arrest. There are several possible reasons for this discrepancy, including employment that was out-of-state, employment in jobs not covered by UI, and false reporting. In analyses
} 


\section{Results}

As background, Figure 1 shows the dynamic patterns of mean labor market outcomes for the inmates in the Florida state system. In order to examine medium-term outcomes where all inmates have been released for at least two years, the analysis is limited to those with incarceration spells of .5 to 4.5 years. This sample of incarceration lengths represents about 80 percent of all individuals committed to prison from 1994:3 - 1995:1. ${ }^{8}$ Prior to the beginning of the incarceration spell, employment rates are quite similar for inmates with differing

incarceration lengths. ${ }^{9}$ Upon release, the employment rate immediately peaks for each group, and then steadily declines until employment rates are approximately the same as they were prior to incarceration. For the fraction of inmates who have quarterly earnings above the poverty level, the relatively flat post-release pattern contrasts with the sharp peaks for employment rates. The implication is that a substantial fraction of each group has positive but very low earnings in the quarters immediately after release, and that these jobs with low earnings do not last long. The fraction with earnings above the poverty rate is about 0.10 prior to the incarceration spell, and this fraction approximately doubles by the seventh year after the spell began. Average quarterly

of the Current Population Survey's April 1993 benefit supplement weighted to reflect the gender, race, education, and age distribution of the Florida inmates, I find that uncovered jobs explain at least half of the gap between the self-reports and administrative reports of employment in these data (Kling, 2004). In other research on job training programs, Robert Kornfeld and Howard Bloom (1999) find that self-reported employment and earnings for adult men are higher than UI reports, with the additional difference apparently due mainly to uncovered jobs rather than out-of-state jobs. Their evaluation of training through the Job Training Partnership Act, focusing on a different but also disadvantaged population, did find that the differences between the treatment and control groups were similar for survey and UI employment rates, even though the levels differed. This provides some evidence that betweengroup differences in UI data can be quite informative for the purposes of following hard-to-track individuals over time and especially for examining outcomes in the mainstream, tax-paying labor market.

${ }^{8}$ This cohort is the earliest that is incarcerated with a year of pre-incarceration earnings and that was subsequent to the period when large numbers of prisoners served a small fractions of their sentences to reduce overcrowding.

${ }^{9}$ The troughs in outcomes at the onset of the spell do not reach zero for several reasons. First, the timing of incarceration spells includes credit for time served in jail; incarceration spells are dated assuming jail time is served continuously but this need not be the case. Second, some individuals are at work release centers where they are allowed to work in the community during the day, recording legitimate earnings. Third, approximately two percent of the SSNs have reported earnings when prison records indicate that the individual was in prison and not at a work release center for the entire quarter -- which implies either that our SSN is incorrect, or that it is being used by someone else during the incarceration spell. 
earnings are also similar across the groups prior to the beginning of the spell, and slightly higher for those with longer incarceration lengths. The figure shows that average earnings seven years after spell initiation are roughly twice the level of pre-spell earnings, reflecting the passage of calendar time and the aging of the cohort in addition to the end of the incarceration spell.

\section{A. Effects on medium-term outcomes controlling for individual differences}

The regression analyses that follow focus on the association of incarceration length with labor market outcomes seven years after the incarceration spell began -- the rightmost points in the graphs shown in Figure 1. Inspection of these unadjusted means in Figure 1 suggests little consistent association between incarceration length and earnings. This inspection is confirmed in the first row of Table 1, which reports the linear regression coefficient using equation (1) with no covariates. ${ }^{10}$ For the Florida data in the first three columns, the point estimates are small and statistically insignificant.

For Florida, controlling for covariates (in the second row of Table 1) has little influence on the coefficient of interest. Additional analyses, with details in Kling (2004), show that the linear specification appears to adequately summarize the incarceration length effect and show that controlling for the higher earnings of those with more serious offenses lowers the incarceration length coefficient, while controlling for the lower human capital of those with longer sentences makes the estimated coefficient incarceration length more positive -- resulting in little net effect. Introducing controls for estimated pre-existing differences (based on outcomes three years prior to the incarceration spell for the 1996:3-1997:1 cohort) in the third row in Table 2 also does not change the estimates appreciably relative to the unadjusted estimates in the first

\footnotetext{
${ }^{10}$ Each observation in these data represents an individual. However, some individuals are co-defendants in the same cases and their outcomes are likely correlated. Case docket numbers are unobserved in the Florida data, but as a rough proxy, the standard errors for analyses of Florida data are adjusted by clustering on the date that the prison spell began on the premise that co-defendants are more likely to enter prison on the same day. Analyses of California data adjust standard errors by clustering on the case docket number.
} 
row. ${ }^{11}$ A parallel analysis for California offenders seven years after their incarceration spells began is given in the fourth through sixth columns of Table 1 . These estimates vary in sign, and as with the Florida results they are small in magnitude and statistically insignificant. ${ }^{12}$

The fourth through seventh rows of Table 1 show results based on equation (4), using the pre-post difference in the outcome as the dependent variable and controlling for actual preexisting differences using data available only in the Florida sample. Additional controls available only in the Florida data are included in the estimation for rows six and seven. The results using these controls are generally similar to the specifications previously discussed, but also show a larger (and in rows five and six, statistically significant) positive coefficient on incarceration length for the outcome of having any positive earnings. In these specifications, an additional year of incarceration is associated with an increase in employment of about 1.6 percentage points.

\section{B. Effects on medium-term outcomes based on instrumental variables analysis}

As discussed in section two, the instrumental variables analysis is based on a different sample than the other analyses, as this research design requires data on all cases randomly assigned to judges. For comparison of this sample with those used in Table 1, results controlling for estimated pre-existing differences using equation (3) are shown in the first row of Table $2 .{ }^{13}$

\footnotetext{
${ }^{11}$ Florida data used in estimation are for the cohort incarcerated beginning in 1994:3-1995:1 with post-spell information seven years later, and the cohort incarcerated beginning 1996:3-1997:1 with pre-spell information three years earlier. Specifically, the pre-spell outcomes are the averages from the tenth, eleventh, and twelfth quarters prior to the incarceration spell. Individuals incarcerated beginning in 1994:3-1995:1 and then incarcerated again beginning in 1996:3-1997:1 are only included as post-spell observations so that each individual has one observation in the estimation.

${ }^{12}$ The estimated pre-spell differences for California in equation (3) are based on the sample of all cases filed 1990:31994:4 with valid earnings data. Earnings data are the average of the tenth, eleventh, and twelfth quarters prior to case filing for individuals ages 25-64 five years after case filing. For individuals with multiple cases, the data from the first observed case was used so that each individual has one observation in the data.

${ }^{13}$ Although 19 percent of these inmates were expected to serve more than 4.5 years, 97 percent of the sample was expected to have been released within nine years after their incarceration spell began. Since this sample is used in the analysis to assess labor market outcomes nine years after case filing, the three percent of the sample with expected spell lengths of more than nine years were top-coded at nine years.
} 
These results are more negative than those using the same specification in Table 1 (in third row), although both sets of results are within sampling error of each other and are close to zero. ${ }^{14}$

The instrumental variables research design has two important stages. The first stage, shown in equation (5), models the relationship between the instrument (the randomly assigned judge) and incarceration length. Since cases are assigned randomly to judges within the same district at a point in time (both between and within offense types) and not all judges were assigned cases throughout the seven years in this sample, equation (5) includes main effects of the six district offices interacted with calendar quarter of case filing. ${ }^{15}$ Given the large number of judges (52) and the moderate joint significance of the judge indicators, I adopt a jackknife estimation approach in which the judge effect for each case is predicted based on estimation using data on all other cases, so that my estimates are not subject to the finite sample bias that can result from weak instruments. ${ }^{16}$ Using this jackknife-predicted judge effect as an

\footnotetext{
${ }^{14}$ Results using models that do not control for pre-existing differences with this sample show stronger and statistically significant negative associations of incarceration length with outcomes. Since these differences are equally evident in the pre-spell earnings, I interpret them as being driven by pre-existing differences.

${ }^{15}$ In analysis of sentencing disparities between judges nationally, James Anderson, Kling, and Kate Stith (1999) show that the introduction of the Federal Sentencing Guidelines for offenses committed after November 1, 1987 very substantially reduced interjudge disparity -- and as a consequence, reduced the power of this instrumental variables research design. Focusing on the period when interjudge disparity was more substantial, the first-stage analysis uses data on federal felony cases filed from January 1981 to October 1987 -- a total of 14,889 cases in six district offices in California. Cases were dropped that were assigned to judges sentencing fewer than 30 total cases, and to senior status judges (to whom cases are not always assigned randomly). There are 52 judges assigned to an average of 286 cases each over this time period.

${ }^{16}$ With main effects for six districts, there are 46 indicator variables for judges included in equation (5). The Fstatistic on the joint test of significance for these judge indicators is 3.9. The importance of finite sample bias in twostage least squares estimation was brought to my attention by John Bound, David A. Jaeger, and Regina M. Baker (1995), and recent reviews of research on this topic are by James Stock, James Wright, and Motohiro Yogo (2002) and Jinyong Hahn and Jerry A. Hausman (2003). The specific jackknife method used is based on the JIVE1 method of Joshua D. Angrist, Guido W. Imbens, and Alan B. Krueger (1999). In JIVE1, however, information on the dependent variable, the endogenous right-hand side variable, and the instrument are available for all observations. While I do have this information for all defendants with valid SSNs, I augment the first-stage estimation with additional information from a second sample of defendants without valid SSNs but with valid sentencing data. Use of a second sample with information on the endogenous right-hand side and the instrument but not the dependent variable is similar in spirit to the two-sample instrumental variable approach of Angrist and Krueger (1995). Use of this second sample, which does not have demographic characteristics of defendants, precludes use of the UIJIVE estimator recommended by Daniel A. Ackerberg and Paul J. Devereux (2006) and Russell Davidson and James G. MacKinnon (2006). In principle, the approach I have adopted makes maximum use of the information available to more precisely estimate judge effects in the first stage while maintaining orthogonality of the instrument with the
} 
instrumental variable in two-stage least squares, the F-statistic for the test of significance of the excluded instrument in the first stage is 40 ; the coefficient is .85 with a standard error of .13. As a check on whether assignment is truly random, I verified that the predicted judge effect was not a significant predictor of inmate characteristics such as race, education, criminal history, or offense type.

The second-stage instrumental variable point estimates reported in Table 2, although statistically insignificant, share the same sign of positive effect of incarceration length on earnings as my preferred specifications using Florida data that control for individual characteristics and actual pre-existing differences (in Table 1 ). ${ }^{17}$ Despite the well-documented interjudge disparity in sentencing and the reasonable significance of the jackknife-predicted judge effect in the first-stage estimation, the estimates are imprecise. Nevertheless, this research design provides a convincing strategy for addressing the potential problem of omitted variable bias by comparing otherwise similar offenders who received shorter or longer sentences due to the randomness of judge assignment. The results help rule out the possibility of large negative effects of incarceration length.

\section{Effects on short-term outcomes}

One of the striking characteristics of the short-run dynamics of labor market outcomes after release was the sharp peak in employment rates around the time of release. The differences in the dynamics associated with incarceration length that were initially presented in Figure 1

errors in the second stage. In practice, the standard errors turn out to be similar to those computed by LIML using each judge indicator as an instrument.

17 The set of all cases assigned to judges includes the eight percent of cases that resulted in dismissals and acquittals. There is essentially no association between the jackknife-predicted judge effect and the probability of dismissal/acquittal, and the results are not sensitive to their exclusion. Based on this evidence, I interpret the instrumental variables coefficients as estimates of the marginal effect of additional prison sentence length. Hausman tests of the differences between the OLS and IV coefficients do not reject the null hypothesis that the models give the same results. The differences in the incarceration length effects between the models are within one standard error of the IV estimates. 
were confounded with the rise in employment rates over calendar time, since the release date of longer incarceration spells is by definition later for a given incarceration date. In order to examine short-run dynamics of the outcomes associated with different incarceration lengths at the same point in calendar time, this section examines inmates released at the same point in time.

To control for observable differences of inmates, I present results in Table 3 that use various models controlling for covariates and actual pre-existing differences, focusing on outcomes one year and two and a half years after release. ${ }^{18}$ In the first three columns, I present results for inmates released from 1999:1-1999:3, while results for inmates released from 2000:32001:1 are in columns 4-6. The results in the first row summarize the strong association of longer incarceration length with positive labor market outcomes for both release cohorts. Comparing results within each of the first three columns of the table, the estimated coefficients become progressively smaller as more controls are included in the estimation both one year after release (in panel A) and two and a half years after release (in panel B). In the fifth row that controls for the richest set of covariates, there is no statistically significant evidence of association between incarceration length and any of the three outcomes. Among the most important controls included the last row (in $\mathrm{X}_{3}$ ) that help explain the short-run association of incarceration length with positive labor market outcomes are those for work release. The importance of controls for factors in more direct control of the correctional system such as programs and post-release supervision (in $\mathrm{X}_{3}$ ), as opposed to offender characteristics (in $\mathrm{X}_{1}$ and $\mathrm{X}_{2}$ ), suggests some scope for the criminal justice system to influence labor market outcomes in

\footnotetext{
${ }^{18}$ One year after release is the average of outcomes 2, 3, and 4 quarters after release. Two and a half years after release is the average of outcomes 8,9 , and 10 quarters after release. The pre-incarceration outcomes are the averages of outcomes 20, 21, and 22 quarters before release. This period is roughly the same point in calendar time for all inmates in this sample and is prior to the incarceration spells (which range from .5 to 4.5 years) so that all inmates would have at least four quarters of labor market data observed prior to their incarceration spells and so that they were incarcerated subsequent to the period when large numbers of prisoners served small fractions of their sentences to reduce overcrowding.
} 
the first two years after release. For results one year after release, the pattern holds of diminishing magnitude in the first three columns when controls are added (for labor market outcomes in 1999 and 2000 when the unemployment rate in Florida was less than 4 percent, its lowest in the past decade), but columns 4-6 show that this pattern is much less pronounced (for outcomes in 2001 and 2002 when the unemployment rate was rising to above 5 percent). These two patterns are not predicted by a simple model in which employers place more emphasis on individual characteristics (correlated with incarceration length) in periods of time when unemployment rates are high and employers can be more selective among applicants.

\section{Discussion of underlying mechanisms}

Various mechanisms through which an increase in incarceration length may affect labor market outcomes are reviewed in this section. One straightforward process is the loss of potential work experience while incarcerated. ${ }^{19}$ If a year of incarceration were purely a loss of one year of labor market experience, this loss of experience could reduce average earnings. In this pre-spell period, 88 percent of individuals are on the upward-sloping portion of the experience-earnings profile, but the slope is relatively flat and the average derivative is only ten dollars of quarterly earnings per year of experience. ${ }^{20}$ I then projected the earnings of all of the inmates eight years forward along this profile, to correspond to the analysis in Table 1, and more than one-third of the sample is on the downward-sloping portion of the experience-earnings profile -- resulting in little net effect of experience, with an average derivative of less than two dollars in quarterly earnings.

\footnotetext{
${ }^{19}$ Although the returns to experience appear to be substantial for low-skilled workers in general (Tricia Gladden and Christopher Taber, 2002), wage growth for individuals after incarceration spells appears to be especially low (Western, 2002).

${ }^{20}$ I examined this by estimating the experience-earnings profile using earnings data one year prior to the spell. Experience is defined as age - schooling - prior years incarcerated - 6 .
} 
Longer incarceration spells could be associated with less recidivism -- specifically, a lower probability of returning to prison. Even if the rate of employment among the nonincarcerated were the same for all groups, for example, lower recidivism for those having served longer incarceration spells could generate higher employment rates when looking at the population of all former inmates (including recidivists and non-recidivists). In order to examine this potential mechanism, I estimated models in which labor market outcomes are treated as randomly-censored when an individual is in prison. Under this approach, when employment and earnings are treated as missing values while an individual is in prison, estimates of the effect of incarceration length are slightly more positive (Kling, 2004). Thus, the overall lack of an observable effect is not a mechanical consequence of negative effects being masked by greater recidivism.

A separate mechanism that could lead to improved labor market outcomes would be participation in academic, vocational, substance abuse treatment, or work release programs while in prison that could increase employment capacity. In analysis of outcomes one year after release from prison, in the previous section, inclusion of controls for these programs, particularly for work release, tended to reduce the positive incarceration length coefficients.

There are a variety of other possible mechanisms that I briefly summarize here and examine in greater detail in Kling (2004) which generate predictions about results for particular subgroups. Human capital may depreciate more if incarceration spells are longer. If longer incarceration increases the chances of being more suited for only unskilled, lower-paying work after release, then I hypothesized in Kling (2004) that the effects of longer incarceration will be more negative for subgroups that had more education and higher earnings prior to incarceration. It is possible that effects of longer incarceration could manifest themselves through stigma, if long spells of non-employment while in prison are more observable to employers, and I 
hypothesized that it would be associated with groups that employers have less prior expectation of being involved in criminal activity, such as whites.

In contrast to mechanisms through which a negative effect of incarceration length on earnings might operate, greater post-release supervision of those with longer incarceration lengths is a direct process that may increase subsequent employment and earnings. An indirect process through which longer incarceration could increase legitimate employment and earnings is by reducing opportunities for illegitimate income, thereby making legitimate work relatively more attractive. I hypothesized that this process would be most important for drug crimes where prospects for illegitimate income may deteriorate with longer incarceration since social interactions are particularly important for drug crimes (Elijah Anderson, 1990). Since the peer influence on illegitimate activity is greatest for younger individuals and reduces with age (Robert J. Sampson and John H. Laub, 2003), I hypothesized that a mechanism connecting longer incarceration to better labor market outcomes (through changes in connections to illegitimate activity caused by removal from the community) is more relevant for individuals who are younger at the onset of their spells.

In Kling (2004), I reported results for subgroups corresponding to each of these hypotheses. Of the seven subgroup comparisons (high school graduate vs. not, employed vs. not, white vs. not, prior incarceration vs. not, post-release supervision vs. not, drug offense vs. not, age $30+$ vs. not), no statistically significant differences between the subgroups were found on employment for any comparison and only one on earnings (those employed at arrest had significantly more positive incarceration length effects - the opposite of the hypothesis). 


\section{Conclusion}

To summarize, this paper uses data from both the Florida state system and the California federal system to examine the effect of incarceration length on subsequent employment and earnings. In the medium term, I find no evidence of a negative effect of incarceration length on employment or earnings in any of the analyses that control for observable factors, account for pre-existing differences, or use instrumental variables for sentence length based on randomly assigned judges. In the short term, I find longer incarceration lengths are associated with more positive labor market outcomes, which can be partially explained by a combination of offender characteristics and conditions of the corrections environment. The similar findings using a variety of research designs and data from two distinctively different criminal justice systems suggest that these findings may have broad applicability.

In analyses centered around time since the incarceration spell began, I find little bias in the simplest unadjusted results relative to the most sophisticated models, controlling for individual observable factors and actual pre-existing differences in labor market outcomes. Within any offense type, the longer sentences tend to be served by individuals with less human capital (e.g., less education), but this pattern is offset in unadjusted analyses by the fact that offense types with longer sentences such as murder or sex crimes tend to involve individuals with better labor market prospects (as measured by their pre-incarceration earnings). Both unadjusted and regression-adjusted analyses show that there is little difference in the average labor market outcomes of inmates prior to incarceration that is related to incarceration length. Although the levels of employment and earnings are much higher for all individuals after incarceration, there is no association between post-release employment and earnings outcomes and incarceration length in the medium term, seven to nine years after incarceration began.

There is a positive association of incarceration length and employment and earnings in 
the short term, one to two years after release from prison. Much of this association can be explained by individual characteristics and by aspects of the incarceration spell itself, such as the amount of time spent at a work release center where the inmate could work in the community prior to release -- although the importance of these mechanisms varies somewhat over calendar time. Controlling for aspects of the spell is helpful in understanding the underlying mechanisms, yet in terms of policy evaluation the relevant estimate may not hold these factors constant. It may be the case that a policy of longer incarceration spells will be bundled with greater program participation and more work release, and that this combination of factors does lead to greater employment and earnings, at least in the first two years after release from prison.

The overall pattern of results is surprising, given previous results in the literature about the negative effects of ever having been incarcerated, the loss of potential work experience while incarcerated, and the likely depreciation of human capital of inmates with longer sentences. My conclusion is that the theoretical mechanisms of lost experience and human capital depreciation are probably at work, but that these effects are small in magnitude for former inmates and are perhaps being offset by prison programs and the withering of social connections to criminal opportunity in communities and peer groups when incarceration spells are longer -- making legitimate work more attractive.

There are many factors that should go into decisions about incarceration length, including those related to sanctions, incapacitation, deterrence, public expense, and spillovers onto victims, inmate families, and communities. However, given my conclusion from this research that the effect of incarceration length on the employment and earnings of individuals after release is positive in the short run and negligible in the medium run, a concern about negative effects of longer incarceration spells on the ability of inmates to reintegrate into the labor market is not one of the factors that should receive much weight in these decisions. 


\section{References}

Ackerberg, Daniel A. and Paul J. Devereux. (2006) "Comment on 'The Case Against JIVE.'” Journal of Applied Econometrics, forthcoming.

Anderson, Elijah. (1990) Streetwise: Race, Class, and Change in an Urban Community. Chicago: University of Chicago Press.

Anderson, James, Jeffrey R. Kling, and Kate Stith. (1999) "Measuring Interjudge Disparity in Sentencing: Before and After the Federal Sentencing Guidelines.” Journal of Law and Economics. 42:1, 271-307.

Angrist, Joshua D., Guido W. Imbens, and Alan B. Krueger. (1999) “Jackknife Instrumental Variables Estimation.” Journal of Applied Econometrics. 14, 57-67.

Angrist, Joshua D. and Alan B. Krueger. (1995) "Split-Sample Instrumental Variables Estimates of the Returns to Schooling.” Journal of Business and Economic Statistics. 13:2, 225235.

Blumstein, Alfred and Allen J. Beck. (1999) “Population Growth in U.S. Prisons, 1980-1996.” In Crime and Justice: Prisons. Edited by Michael Tonry and Joan Petersilia. Chicago: University of Chicago Press, 17-62.

Bonczar, Thomas P. (2003) Prevalence of Imprisonment in the U.S. Population, 1974-2001 (NCJ 197976). Washington, DC: Bureau of Justice Statistics.

Bushway, Shawn and Peter Reuter. (2002) “Labor Markets and Crime.” In Crime: Public Policies for Crime Control. Edited by James Q. Wilson and Joan Petersilia. Oakland, CA: Institute for Contemporary Studies, 191-224.

Davidson, Russell and James G. MacKinnon. (2006) "Reply to Comment on 'The Case Against JIVE."” Journal of Applied Econometrics, forthcoming.

Ditton, Paula M. and Doris J. Wilson. (1999) Truth in Sentencing in State Prisons (NCJ 170032). Washington, D. C.: Bureau of Justice Statistics.

Freeman, Richard B. (1992) “Crime and the Employment of Disadvantaged Youth.” In Urban Labor Markets and Job Opportunity. Edited by George Peterson and Wayne Vroman. Washington, DC: Urban Institute Press, 201-237.

Freeman, Richard B. (1999) “The Economics of Crime.” In Handbook of Labor Economics, vol. 3A. Edited by Orley Ashenfelter and David Card. Amsterdam: North Holland, 35293572.

Gladden, Tricia and Christopher Taber. (2002) "Wage Progression Among Less-Skilled Workers.” In Finding Jobs: Work and Welfare Reform. Edited by David E. Card and Rebecca M. Blank. New York: Russell Sage Foundation Press, 160-232.

Grogger, Jeffrey. (1995) “The Effect of Arrests on the Employment and Earnings of Young Men.” Quarterly Journal of Economics. 110:1, 51-71.

Hahn, Jinyong and Jerry A. Hausman. (2003) "Weak Instruments: Diagnosis and Cures in Empirical Economics.” American Economic Review. 93:2, 118-125.

Harlow, Caroline Wolf. (1994) Comparing Federal and State Prison Inmates 1991 (NCJ 145864). Washington, DC: Bureau of Justice Statistics.

Harrison, Paige M. (2002) Correctional Populations in the United States, 1998: Prisoners (NCJ 192929). Washington, DC: Bureau of Justice Statistics. 
Harrison, Paige M. and Jennifer C. Karberg. (2003) Prison and Jail Inmates at Midyear 2003 (NCJ 203947). Washington, DC: Bureau of Justice Statistics.

Kling, Jeffrey R. (2004) “Incarceration Length, Employment, and Earnings.” Princeton IRS Working Paper 494.

Kornfeld, Robert and Howard Bloom. (1999) "Measuring Program Impacts on Earnings and Employment: Do Unemployment Insurance Wage Records Agree with Survey Reports of Individuals?” Journal of Labor Economics. 17:1, 168-197.

Lott, John R. (1992a) “An Attempt at Measuring The Total Monetary Penalty From Drug Convictions: The Importance of an Individual's Reputation.” Journal of Legal Studies. 21, 159-187.

Lott, John R. (1992b) “Do We Punish High Income Criminals Too Heavily?” Economic Inquiry. 30:4, 583-608.

Lynch, James P. and William J. Sabol. (2001) Prisoner Reentry in Perspective. Washington, DC: The Urban Institute.

Nagin, Daniel and Joel Waldfogel. (1995) "The Effects of Criminality and Conviction on the Labor Market Status of Young British Offenders.” International Review of Law and Economics. 15:1, 109-126.

Needels, Karen E. (1996) “Go Directly to Jail and Do Not Collect? A Long-term Study of Recidivism, Employment, and Earnings Patterns among Prison Releasees.” Journal of Research in Crime and Delinquency. 33:4, 471-496.

Pettit, Becky and Christopher Lyons. (2006) "Status and the Stigma of Incarceration: The Labor Market Effects of Incarceration by Race, Class, and Criminal Involvement.” In The Impact of Incarceration on Labor Market Outcomes. Edited by Shawn D. Bushway, Michael A. Stoll, and David F. Weiman. New York: Russell Sage Foundation Press. Forthcoming.

Sabol, William J. (2006) “Local Labor Market Conditions and Post-prison Employment Experience of Offenders Released from Ohio Prisons.” In The Impact of Incarceration on Labor Market Outcomes. Edited by Shawn D. Bushway, Michael A. Stoll, and David F. Weiman. New York: Russell Sage Foundation Press. Forthcoming.

Sabol, William J. and John McGready. (1999) Time Served in Prison by Federal Offenders, 1986-97 (NCJ 171682). Washington DC: Bureau of Justice Statistics.

Sampson, Robert J. and John H. Laub. (2003) "Life-Course Desisters? Trajectories of Crime Among Delinquent Boys Followed to Age 70.” Criminology. 41:3, 555-592.

Stock, James, James Wright, and Motohiro Yogo. (2002) “A Survey of Weak Instruments and Weak Identification in GMM.” Journal of Business and Economic Statistics. 20:4, 518-29.

U.S. Department of Justice. (1996) Compendium of Federal Justice Statistics, 1993 (NCJ 160089). Washington, DC: Bureau of Justice Statistics.

Waldfogel, Joel. (1994) “The Effect of Criminal Conviction on Income and the Trust 'Reposed in the Workmen.'” Journal of Human Resources. 29:1, 62-81.

Western, Bruce, Jeffrey R. Kling, and David F. Weiman. (2001) “The Labor Market Consequences of Incarceration.” Crime and Delinquency. 47:3, 410-427.

Western, Bruce. (2002) “Incarceration, Wages, and Inequality.” American Sociological Review. $67: 4,526-546$. 
Figure 1. Labor Market Outcomes by Time Since Incarceration, State System in Florida

A. Fraction with any earnings

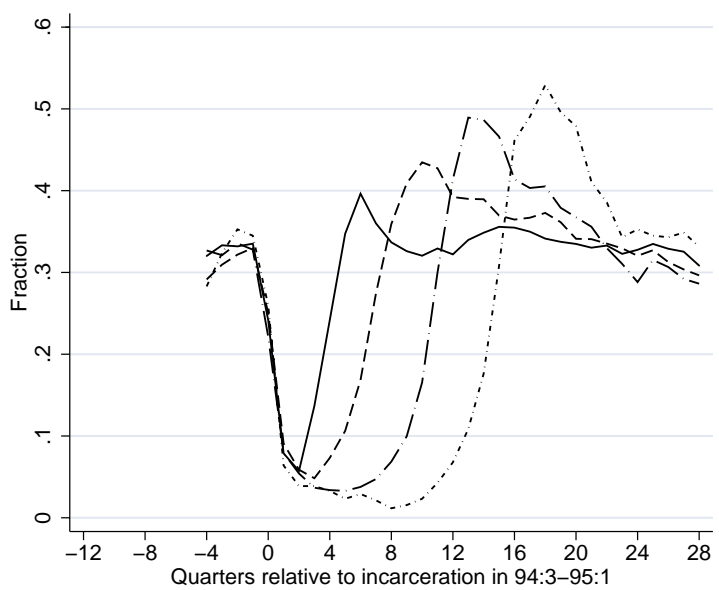

B. Fraction with earnings above poverty rate

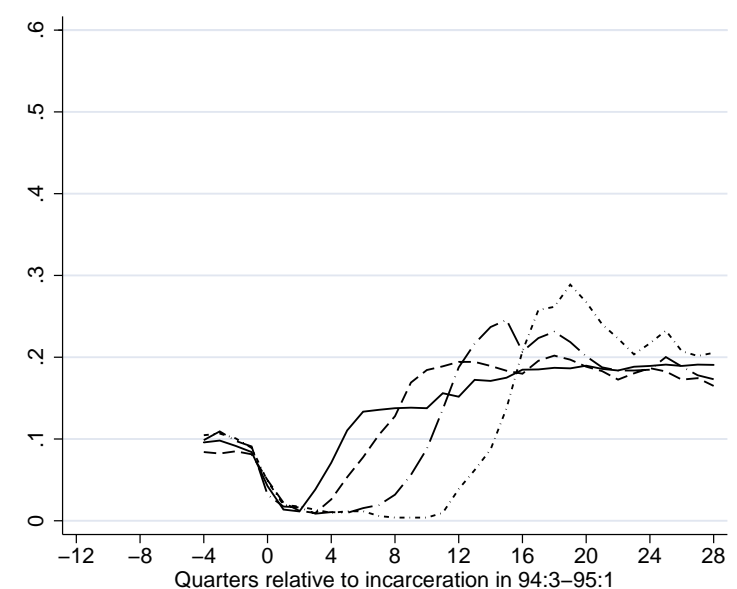

C. Average quarterly earnings

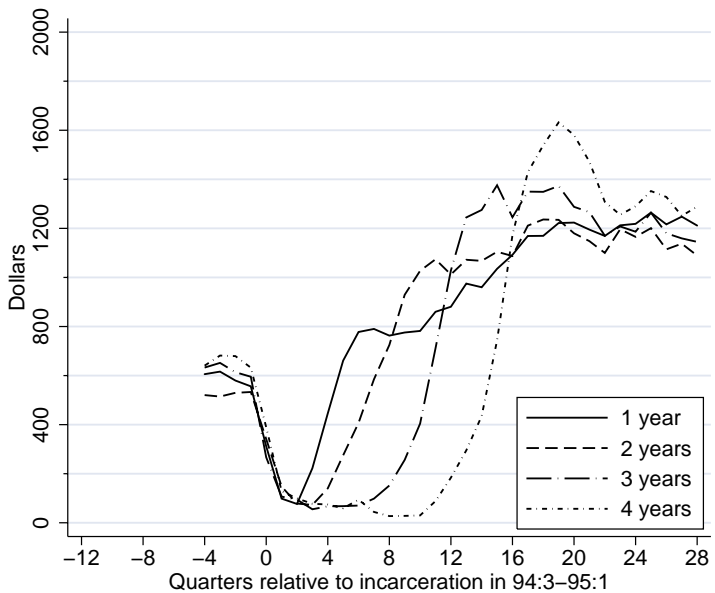

Notes. Sample was incarcerated 1994:3-1995:1, and are ages 25-64 seven years after incarceration began. Incarceration lengths: 1 year = 6-17 months; 2 years $=18-29$ months; 3 years $=30-41$ months; 4 years $=42-53$ months. Poverty threshold is for single adult under age 65 . Real 2002 dollars based on seasonally-adjusted national CPI. Quarterly earnings data from 1993:3 - 2002:1. 
Table 1

Effects of an Additional Year of Incarceration

on Labor Market Outcomes Seven Years After Incarceration Began

\begin{tabular}{|c|c|c|c|c|c|c|}
\hline & \multicolumn{3}{|c|}{ State System in Florida } & \multicolumn{3}{|c|}{ Federal System in California } \\
\hline & $\begin{array}{l}\text { Earnings } \\
>\text { zero }\end{array}$ & $\begin{array}{l}\text { Earnings } \\
>\text { poverty }\end{array}$ & $\begin{array}{c}\text { Average } \\
\text { earnings }\end{array}$ & $\begin{array}{l}\text { Earnings } \\
>\text { zero }\end{array}$ & $\begin{array}{l}\text { Earnings } \\
>\text { poverty }\end{array}$ & $\begin{array}{c}\text { Average } \\
\text { earnings }\end{array}$ \\
\hline No controls; eq (1): $\gamma_{1}$ & $\begin{array}{l}-.0008 \\
(.0052)\end{array}$ & $\begin{array}{l}.0019 \\
(.0045)\end{array}$ & $\begin{array}{c}6 \\
(32)\end{array}$ & $\begin{array}{l}-.0009 \\
(.0071)\end{array}$ & $\begin{array}{l}.0006 \\
(.0064)\end{array}$ & $\begin{array}{l}-52 \\
(70)\end{array}$ \\
\hline Controls for X; eq (2): $\gamma_{2} \mid X_{1}$ & $\begin{array}{l}.0007 \\
(.0054)\end{array}$ & $\begin{array}{l}.0021 \\
(.0046)\end{array}$ & $\begin{array}{c}9 \\
(34)\end{array}$ & $\begin{array}{l}-.0082 \\
(.0081)\end{array}$ & $\begin{array}{l}-.0054 \\
(.0073)\end{array}$ & $\begin{array}{l}-122 \\
(80)\end{array}$ \\
\hline $\begin{array}{l}\text { Controls for X \& estimated } \\
\text { pre-existing diffs; eq (3): } \gamma_{31} \mid X_{1}\end{array}$ & $\begin{array}{l}.0020 \\
(.0071)\end{array}$ & $\begin{array}{l}-.0016 \\
(.0055)\end{array}$ & $\begin{array}{l}-18 \\
(37)\end{array}$ & $\begin{array}{c}.0050 \\
(.0096)\end{array}$ & $\begin{array}{l}.0012 \\
(.0087)\end{array}$ & $\begin{array}{l}-33 \\
(95)\end{array}$ \\
\hline $\begin{array}{l}\text { Controls for actual pre-existing } \\
\text { diffs; eq (4): } \gamma_{4}\end{array}$ & $\begin{array}{c}.0008 \\
(.0067)\end{array}$ & $\begin{array}{l}-.0012 \\
(.0049)\end{array}$ & $\begin{array}{l}-13 \\
(34)\end{array}$ & & & \\
\hline $\begin{array}{l}\text { Controls for X \& actual pre- } \\
\text { existing diffs; eq (4): } \gamma_{4} \mid \mathrm{X}_{1}\end{array}$ & $\begin{array}{l}.0152 * \\
(.0067)\end{array}$ & $\begin{array}{l}.0043 \\
(.0050)\end{array}$ & $\begin{array}{c}19 \\
(35)\end{array}$ & & & \\
\hline $\begin{array}{l}\text { Controls for X \& actual pre- } \\
\text { existing diffs; eq (4): } \gamma_{4} \mid X_{1}, X_{2}\end{array}$ & $\begin{array}{l}.0157^{*} \\
(.0068)\end{array}$ & $\begin{array}{l}.0060 \\
(.0050)\end{array}$ & $\begin{array}{c}33 \\
(36)\end{array}$ & & & \\
\hline $\begin{array}{l}\text { Controls for X \& actual pre- } \\
\text { existing diffs; eq (4): } \gamma_{4} \mid X_{1}, X_{2}, X_{3}\end{array}$ & $\begin{array}{c}.0088 \\
(.0077)\end{array}$ & $\begin{array}{l}.0016 \\
(.0059)\end{array}$ & $\begin{array}{c}4 \\
(41)\end{array}$ & & & \\
\hline
\end{tabular}

Notes. Each cell contains the coefficient on years of incarceration from a separate regression. The estimation equation, "eq," from section one is listed for each row. Earnings $>0$ is the fraction of calendar quarters with any positive earnings. Earnings > poverty is the fraction of quarters with earnings above the poverty threshold of $\$ 2340$ per quarter. Average earnings are average quarterly earnings, including zeros. Robust standard errors are in parentheses. $*=$ p-value $<.05$.

Florida sample is composed of inmates incarcerated 1994:3-1995:1, ages 25-64 seven years later, with actual incarceration lengths of .5-4.5 years, and with valid earnings data. For Florida data, $\mathrm{X}_{1}$ consists of the following variables. Age when earnings observed. Age squared. Indicator for gender. Two indicators for race. Ten indicators for education. Six indicators for prior incarceration history. Nine indicators for primary offense type. Indicator for self-report of whether employed at time of arrest. Three indicators for calendar quarter of estimated incarceration initiation. $\mathrm{X}_{2}$ consists of the following variables. 32 indicators for reading and math test scores. Indicator for English as second language. Three indicators for marital status. Three indicators for state of birth. Five indicators for self-reported substance use history. Three indicators for history of disciplinary reports. Twelve indicators for health status. $\mathrm{X}_{3}$ consists of the following variables. Two indicators for custody level. Indicator for post-release supervision. One indicator for passing GED exam. Six indicators for any time in vocational education, in GED courses, in remedial academic education, in substance abuse treatment, in prison industry, or at work release center. Six variables for number of hours in vocational education, in GED courses, in remedial academic education, in substance abuse treatment, in prison industry, or at work release center.

California sample is inmates with expected prison terms of .5-4.5 years with valid earnings data, cases filed 1983:2-1990:2, ages 25-64 seven years later. For California data, $\mathrm{X}_{1}$ consists of the following variables. Age when earnings observed. Age squared. Indicator for gender. Four indicators for race. Three indicators for education. Four indicators for prior criminal history. Twenty indicators for offense type. Indicators for selfreport of whether employed at arrest and for missing data on employment. Twenty-eight indicators for calendar quarter of case filing. 
Table 2

OLS and Instrumental Variables Estimates of Effects of an Additional Year of Incarceration on Labor Market Outcomes Nine Years After Incarceration Began

\begin{tabular}{lccc}
\hline \hline & \multicolumn{3}{c}{ Federal System in California } \\
\cline { 2 - 4 } & Earnings > zero & Earnings > poverty & Average earnings \\
\hline Controls for X \& estimated pre-existing & -.0031 & -.0038 & -44 \\
diffs; eq (3): $\gamma_{31} \mid \mathrm{X}_{1}$ & $(.0031)$ & $(.0028)$ & $(32)$ \\
Controls for X \& uses instrumental & .0169 & .0069 & 248 \\
$\quad$ variables from eq (5) for 2SLS & $(.0267)$ & $(.0246)$ & $(294)$ \\
estimation of eq (2): $\gamma_{2} \mid \mathrm{X}_{1}$ & & & \\
\hline
\end{tabular}

Notes. Each cell contains the coefficient on years of incarceration from a separate regression. Results in row 1 control for $X_{1}$ and estimate pre-existing differences from equation (3), using $X_{1}$ as defined in the notes for Table 1. The sample used for post-incarceration earnings includes individuals with expected prison terms of .5-4.5 years with valid earnings data, cases filed 1983:2-1990:2, ages 25-64 seven years later. Sample size is 4610. The sample used for pre-incarceration earnings includes individuals ages 25-64 five years after case filing for cases filed 1990:3-1994:4. Sample size is 8219. Earnings data are the average of the tenth, eleventh, and twelfth quarters prior to case filing. Both the pre- and post-spell samples are limited to cases where the judge was randomly assigned. For individuals with multiple cases, the data from the first observed case was used so that each individual has one observation in the data.

Results in row 2 use equation (5) to form a jackknife estimate of the predicted incarceration length based on the judge assigned to the case, which is then used as an excluded instrument in two-stage least squares estimation of equation (2). Sample is all defendants with cases filed prior to 11/1/1987 with valid earnings data, ages 25-64 nine years later. Sample size is 4609. Earnings $>0$ is the fraction of calendar quarters with any positive earnings. Earnings $>$ poverty is the fraction of quarters with earnings above the poverty threshold of $\$ 2340$ per quarter. Average earnings are average quarterly earnings, including zeros. Robust standard errors are in parentheses. ${ }^{*}=$ p-value $<.05$. 
Table 3

Effects on Labor Market Outcomes of an Additional Year of Incarceration by Time Since Release for Two Release Cohorts

\begin{tabular}{|c|c|c|c|c|c|c|}
\hline & \multicolumn{6}{|c|}{ State System in Florida } \\
\hline & \multicolumn{3}{|c|}{ Released 1999:1-1999:3 } & \multicolumn{3}{|c|}{ Released 2000:3-2001:1 } \\
\hline & $\begin{array}{l}\text { Earnings } \\
>\text { zero }\end{array}$ & $\begin{array}{l}\text { Earnings } \\
>\text { poverty }\end{array}$ & $\begin{array}{c}\text { Average } \\
\text { earnings }\end{array}$ & $\begin{array}{c}\text { Earnings } \\
>\text { zero }\end{array}$ & $\begin{array}{l}\text { Earnings } \\
>\text { poverty }\end{array}$ & $\begin{array}{l}\text { Average } \\
\text { earnings }\end{array}$ \\
\hline \multicolumn{7}{|l|}{ A. One year after release } \\
\hline No controls; eq (1): $\gamma_{1}$ & $\begin{array}{l}.0232 * \\
(.0063)\end{array}$ & $\begin{array}{l}.0395 * \\
(.0057)\end{array}$ & $\begin{array}{l}199 * \\
(35)\end{array}$ & $\begin{array}{l}.0232^{*} \\
(.0054)\end{array}$ & $\begin{array}{l}.0286^{*} \\
(.0047)\end{array}$ & $\begin{array}{l}164^{*} \\
(30)\end{array}$ \\
\hline Controls for $X$; eq (2): $\gamma_{2} \mid X_{1}$ & $\begin{array}{l}.0157^{*} \\
(.0069)\end{array}$ & $\begin{array}{l}.0319 * \\
(.0062)\end{array}$ & $\begin{array}{l}156^{*} \\
(39)\end{array}$ & $\begin{array}{l}.0213^{*} \\
(.0059)\end{array}$ & $\begin{array}{l}.0250 * \\
(.0049)\end{array}$ & $\begin{array}{l}135^{*} \\
(31)\end{array}$ \\
\hline $\begin{array}{l}\text { Controls for actual pre-existing } \\
\text { diffs; eq (4): } \gamma_{4}\end{array}$ & $\begin{array}{l}.0086 \\
(.0076)\end{array}$ & $\begin{array}{l}.0337 * \\
(.0066)\end{array}$ & $\begin{array}{l}136 * \\
(38)\end{array}$ & $\begin{array}{l}.0238^{*} \\
(.0068)\end{array}$ & $\begin{array}{l}.0256 * \\
(.0052)\end{array}$ & $\begin{array}{l}153^{*} \\
(31)\end{array}$ \\
\hline $\begin{array}{l}\text { Controls for X \& actual pre- } \\
\text { existing diffs; eq (4): } \gamma_{4} \mid X_{1}, X_{2}\end{array}$ & $\begin{array}{l}-.0022 \\
(.0094)\end{array}$ & $\begin{array}{l}.0249 * \\
(.0082)\end{array}$ & $\begin{array}{l}93 * \\
(47)\end{array}$ & $\begin{array}{l}.0218 * \\
(.0105)\end{array}$ & $\begin{array}{l}.0241 * \\
(.0075)\end{array}$ & $\begin{array}{l}153^{*} \\
(50)\end{array}$ \\
\hline $\begin{array}{l}\text { Controls for X \& actual pre- } \\
\text { existing diffs; eq (4): } \gamma_{4} \mid \mathrm{X}_{1}, \mathrm{X}_{2}, \mathrm{X}_{3}\end{array}$ & $\begin{array}{l}-.0168 \\
(.0106)\end{array}$ & $\begin{array}{c}.0121 \\
(.0091)\end{array}$ & $\begin{array}{c}10 \\
(53)\end{array}$ & $\begin{array}{l}.0113 \\
(.0111)\end{array}$ & $\begin{array}{l}.0193^{*} \\
(.0080)\end{array}$ & $\begin{array}{l}116^{*} \\
(52)\end{array}$ \\
\hline \multicolumn{7}{|l|}{ B. Two and a half years after release } \\
\hline No controls; eq (1): $\gamma_{1}$ & $\begin{array}{l}.0198 * \\
(.0063)\end{array}$ & $\begin{array}{l}.0239^{*} \\
(.0054)\end{array}$ & $\begin{array}{l}138 * \\
(37)\end{array}$ & & & \\
\hline Controls for $X$; eq (2): $\gamma_{2} \mid X_{1}$ & $\begin{array}{l}.0155^{*} \\
(.0069)\end{array}$ & $\begin{array}{l}.0218 * \\
(.0059)\end{array}$ & $\begin{array}{l}117 * \\
(41)\end{array}$ & & & \\
\hline $\begin{array}{l}\text { Controls for actual pre-existing } \\
\text { diffs; eq (4): } \gamma_{4}\end{array}$ & $\begin{array}{l}.0052 \\
(.0080)\end{array}$ & $\begin{array}{l}.0180 * \\
(.0064)\end{array}$ & $\begin{array}{c}75 \\
(39)\end{array}$ & & & \\
\hline $\begin{array}{l}\text { Controls for X \& actual pre- } \\
\text { existing diffs; eq (4): } \gamma_{4} \mid X_{1}, X_{2}\end{array}$ & $\begin{array}{l}-.0016 \\
(.0097)\end{array}$ & $\begin{array}{l}.0160 * \\
(.0078)\end{array}$ & $\begin{array}{c}61 \\
(50)\end{array}$ & & & \\
\hline $\begin{array}{l}\text { Controls for } \mathrm{X} \& \text { actual pre- } \\
\text { existing diffs; eq (4): } \gamma_{4} \mid \mathrm{X}_{1}, \mathrm{X}_{2}, \mathrm{X}_{3}\end{array}$ & $\begin{array}{l}-.0199 \\
(.0107)\end{array}$ & $\begin{array}{l}.0040 \\
(.0088)\end{array}$ & $\begin{array}{l}-40 \\
(55)\end{array}$ & & & \\
\hline
\end{tabular}

Notes. Panel A is for outcomes up to 1 year after release, and panel B is for up to 2.5 years after release. Each cell contains the coefficient on years of incarceration from a separate regression. The estimation equation, "eq," from section one is listed for each row. Samples are ages 25-64 two and a half years after release, with actual incarceration lengths of .5-4.5 years, and with valid earnings data. Earnings $>0$ is the fraction of calendar quarters with any positive earnings. Earnings $>$ poverty is the fraction of quarters with earnings above the poverty threshold of $\$ 2340$ per quarter. Average earnings are average quarterly earnings, including zeros. Covariates $X$ are as described in the notes to Table 1 . Sample size is 6658 for cohorts released 1999:1-1999:3, and 8605 for cohorts released 2000:3-2001:1. Robust standard errors are in parentheses. $*=$ p-value $<.05$. 


\section{Data Appendix}

The data used in this paper come from the administrative records of the state prison system in Florida and the federal judicial system in California, each linked to state administrative records about quarterly earnings. The Florida data were produced for this study in collaboration with the Florida Department of Corrections (FLDOC). The data were compiled by linking separate FLDOC files on correctional institution admission and release dates, jail credits, admission file demographics (filling in missing data with subsequent monthly status files), reception center test scores, and correctional institution disciplinary reports. Social Security Numbers (SSNs) from admission files were verified by the Social Security Administration (SSA) using their Employment Verification Service, matching names, birthdates, and race to SSA records of SSNs. The Florida Education and Training Placement Information Program matched quarterly earnings data for 1993:3 through 2002:1 from the UI system to the FLDOC data. The Florida Department of Law Enforcement provided arrest records.

The California data were produced under special confidential data-sharing agreements with the Administrative Office of the U.S. Courts (for data on terminated federal cases with individual and judge identifiers), the U.S. Bureau of Justice Statistics (for demographic data and SSNs) ${ }^{21}$, and the California Employment Development Department (for quarterly UI data from 1987:2 to 1997:1, linked by SSN). ${ }^{22}$

\footnotetext{
${ }^{21}$ Data archived with the U.S. Bureau of Justice Statistics was used with the permission of U.S. Pre-trial Services in the Central, Eastern, Northern, and Southern Districts of California

${ }^{22}$ Because the sentencing data did not contain unique individual identifiers, the sentencing data were linked to pretrial services data using probabilistic matching techniques relying upon non-unique identifiers of name, date, and offense type. In a pilot study of Massachusetts cases that did have unique identifiers, the matching logic and clerical review identified approximately 98 percent of all true matches with only .15 percent false matches. Despite this success, SSNs and demographic information were not collected in all years for each California district, resulting in a loss of 42 percent of the potential sample from 1983-94. A further 15 percent of the sample, which appear to be mainly immigrants, did not report SSNs. These data are collected prior to the assignment of a judge to the case, and reporting lapses appear to be independent of judge assignment.
} 
Descriptive statistics for these data are shown in Appendix Table A. The first two columns show characteristics of the Florida prisoners in the data. ${ }^{23}$ The sample of inmates in column one began their incarceration spells in the calendar quarters 1994:3-1995:1. Given the available labor market outcome data, they are observed for four quarters prior to incarceration and 28 quarters after the incarceration spell began. In order to examine medium-term outcomes where all inmates have been released for at least two years (in Table 1), the analysis is limited to those with incarceration spells of no more than 4.5 years. I further limit the analysis to spells of at least six months, since nearly all shorter incarceration spells in Florida take place in local jails and not in the state prison system. This sample of incarceration lengths represents about 80 percent of all individuals committed to prison. ${ }^{24}$ The sample used to analyze effects of incarceration length shortly after release during the same period of calendar time (in Table 3) is described in column two, including releases in 1999:1-1999:3. This sample is slightly older, due to the restriction for subsequent analysis that all members of this sample be ages 25-64 two and a half years after release, but is otherwise quite similar to that in column one.

There are two main analytical samples based on California data. The third column of Appendix Table A describes a sample constructed to parallel that for Florida in column one, with expected incarceration spells of .5-4.5 years (used in Table 1). Actual time served is not observed in the California data, so the expected spell length is based on the sentence length and historical averages of proportion of time served published by the U.S. Department of Justice (1996). The fourth column describes the data used to estimate the instrumental variables model (in Table 2),

\footnotetext{
${ }^{23}$ Only new commitments to prison are used, not spells of incarceration that began in this period due to return to prison for violation of post-release conditions. The sample is also limited to those reporting that they were U.S. citizens and Florida residents at the time of arrest and to those released to a Florida destination in order to reduce the influence of out-of-state mobility on the results.

${ }^{24}$ For the cohort incarcerated 1994:3-1995:1, 1.5 percent served less than 6 months and 17.5 percent served more than 4.5 years.
} 
which includes all cases that were randomly assigned to judges and have valid earnings data nine years after case filing. Although 19 percent of these inmates were expected to serve more than 4.5 years, 97 percent of the sample was expected to have been released within nine years after their incarceration spell began. Since this sample is used in the analysis to assess labor market outcomes nine years after case filing, the three percent of the sample with expected spell lengths of more than nine years were top-coded at nine years.

For simplicity, the quarterly earnings data in this table and in regression analyses in the paper consist of a single summary measure of pre-spell labor market outcomes for each individual, averaging over three calendar quarters to reduce transitory variability. ${ }^{25}$ Similarly, post-spell outcomes are the averages over three quarters. ${ }^{26}$

\footnotetext{
${ }^{25}$ In column one, pre-spell outcomes are the averages of the 2nd, 3rd, and 4th quarters prior to the incarceration spell. In column two, pre-spell outcomes are the averages of the 22nd, 21st, and 20th quarters prior to release. ${ }^{26}$ In column one, post-spell outcomes are the averages of the 26th, 27th, and 28th quarters after the incarceration spell. In column two, post-spell outcomes are the averages of the 8th, 9th, and 10th quarters after release.
} 
Appendix Table A

Descriptive Statistics

\begin{tabular}{|c|c|c|c|c|}
\hline & $\begin{array}{c}\text { Florida } \\
\text { Incarcerated } \\
\text { 1994:3-95:1 }\end{array}$ & $\begin{array}{c}\text { Florida } \\
\text { Released } \\
\text { 1999:1-99:3 }\end{array}$ & $\begin{array}{c}\text { California } \\
\text { OLS sample }\end{array}$ & $\begin{array}{l}\text { California } \\
\text { IV sample }\end{array}$ \\
\hline No Incarceration & .00 & .00 & .00 & .37 \\
\hline Incarceration less than 6 months & .00 & .00 & .00 & .17 \\
\hline 1 year incarceration (6-17 months) & .45 & .43 & .29 & .08 \\
\hline 2 years incarceration (18-29 months) & .32 & .33 & .20 & .05 \\
\hline 3 years incarceration (30-41 months) & .15 & .16 & .27 & .08 \\
\hline 4 years incarceration (42-53 months) & .08 & .08 & .24 & .06 \\
\hline $5+$ years incarceration (54+ months) & .00 & .00 & .00 & .19 \\
\hline Male & .92 & .88 & .90 & .84 \\
\hline White & .42 & .40 & .57 & .63 \\
\hline Black & .54 & .56 & .17 & .17 \\
\hline Hispanic & .04 & .04 & .17 & .15 \\
\hline Other race & .00 & .00 & .09 & .06 \\
\hline Ages $18-29$ at incarceration & .55 & .42 & .35 & .38 \\
\hline Ages 30-39 at incarceration & .34 & .40 & .37 & .38 \\
\hline Ages $40+$ at incarceration & .11 & .18 & .28 & .24 \\
\hline Education unknown & .01 & .00 & .29 & .34 \\
\hline Less than high school & .72 & .69 & .21 & .20 \\
\hline Completed high school & .21 & .23 & .24 & .24 \\
\hline Completed at least some college & .06 & .07 & .25 & .23 \\
\hline Prior incarceration & .48 & .49 & .34 & .26 \\
\hline Violent or firearms offense & .35 & .31 & .23 & .25 \\
\hline Drug offense & .28 & .33 & .34 & .25 \\
\hline Property offense & .34 & .31 & .32 & .38 \\
\hline Other offense & .03 & .06 & .11 & .12 \\
\hline Self-reported employment unknown & .00 & .00 & .25 & .30 \\
\hline Self-reported not employed at arrest & .35 & .34 & .38 & .33 \\
\hline Self-reported employed at arrest & .65 & .66 & .37 & .37 \\
\hline Pre-spell quarterly earnings fraction $>\$ 0$ & .32 & .31 & $\mathrm{n} / \mathrm{a}$ & $\mathrm{n} / \mathrm{a}$ \\
\hline Pre-spell quarterly earnings fraction $>\$ 2340$ & .09 & .12 & $\mathrm{n} / \mathrm{a}$ & $\mathrm{n} / \mathrm{a}$ \\
\hline Pre-spell quarterly earnings average & 585 & 718 & $\mathrm{n} / \mathrm{a}$ & $\mathrm{n} / \mathrm{a}$ \\
\hline Post-spell quarterly earnings fraction $>\$ 0$ & .31 & .34 & .26 & .26 \\
\hline Post-spell quarterly earnings fraction $>\$ 2340$ & .18 & .20 & .20 & .21 \\
\hline Post-spell quarterly earnings average & 1184 & 1290 & 1809 & 1985 \\
\hline Sample size & 6821 & 6658 & 2575 & 4610 \\
\hline
\end{tabular}

Notes. Florida sample incarcerated 1994:3-1995:1 is ages 25-64 seven years later. Florida sample released 1999:1-1999:3 is ages 25-64 two and a half years after release. Both Florida samples are of inmates with actual incarceration lengths of .5-4.5 years, with valid earnings data. California OLS sample is inmates with expected prison terms of .5-4.5 years with valid earnings data, cases filed 1983:2-1990:2, ages 25-64 seven years later. California IV sample is all defendants with cases filed prior to 11/1/1987 with valid earnings data, ages 25-64 nine years later. \$2340 is one quarter of the 2002 poverty threshold for a single adult, \$9359. Quarterly earnings adjusted to 2002 real dollars based on seasonally-adjusted national CPI. 